\title{
Impact of lunch provision on anthropometry, hemoglobin, and micronutrient status of female Cambodian garment workers: exploratory randomized controlled trial
}

\author{
Jan Makurat $^{1 *}$ D, Natalie Becker ${ }^{1}$, Frank T. Wieringa ${ }^{2}$, Chhoun Chamnan ${ }^{3}$ and Michael B. Krawinkel ${ }^{1}$
}

\begin{abstract}
Background: Lunch provision is expected to improve the nutritional status of Cambodian garment workers. The objective of this study is to evaluate the effects of a model lunch provision through a canteen on anthropometry, hemoglobin, and micronutrient status in female garment workers in Cambodia.

Methods: This exploratory randomized controlled trial was implemented at a garment factory in Phnom Penh, Cambodia. Female workers (nulliparous, non-pregnant) were recruited and randomly allocated into an intervention arm (workday's lunch provision) and a control arm. Served lunch sets ( $700 \mathrm{kcal}$ on average) included diverse local dishes. Anthropometry (body mass index, weight, triceps skinfold thickness, and mid-upper arm muscle circumference), as well as hemoglobin, serum ferritin and soluble transferrin receptor, serum retinol binding protein, and serum folate concentrations were assessed at baseline and after 5 months of lunch provision. A general linear model with adjustments for baseline values was used to estimate intervention effects for each outcome variable.

Results: Two hundred twenty-three women were recruited ( $n=112$ control and $n=111$ intervention). 172 ( $n=86$ in each arm) completed the study. Baseline prevalence of underweight, anemia, depleted iron stores, and marginal iron stores, were 31, 24, 21, and 50\%, respectively. Subjects were not affected by frank vitamin A or folate deficiency, whereas $30 \%$ showed a marginal folate status. Overall, mean changes in anthropometric variables, hemoglobin, and retinol binding protein were marginal and not significant among intervention subjects. Mean folate concentration increased insignificantly by $+1.1 \mathrm{ng} / \mathrm{mL}(-0.02,2.2)(p=0.054)$. On the other hand, mean ferritin decreased by $-6.6 \mu \mathrm{g} / \mathrm{L}(-11.9$, 1.3) $(p=0.015)$. Subgroup analysis prompts that effects are differently pronounced according to the baseline status of workers.
\end{abstract}

Conclusions: Findings indicate that model lunch sets provided a beneficial amount of dietary folate, but need to be revisited for iron content and/or iron bioavailability. It is believed that distinct positive effects on anthropometry, hemoglobin, and micronutrient status can solely be expected in malnourished individuals. The authors suggest that similar larger trials, which include sets adapted to the concrete needs of workers affected by underweight, anemia and/or definite micronutrient deficiencies, should be performed.

(Continued on next page)

\footnotetext{
* Correspondence: jan.makurat@ernaehrung.uni-giessen.de

${ }^{1}$ Institute of Nutritional Sciences, Justus Liebig University Giessen,

Wilhelmstrasse 20, 35392 Giessen, Germany

Full list of author information is available at the end of the article
}

(c) The Author(s). 2019 Open Access This article is distributed under the terms of the Creative Commons Attribution 4.0 International License (http://creativecommons.org/licenses/by/4.0/), which permits unrestricted use, distribution, and reproduction in any medium, provided you give appropriate credit to the original author(s) and the source, provide a link to the Creative Commons license, and indicate if changes were made. The Creative Commons Public Domain Dedication waiver (http://creativecommons.org/publicdomain/zero/1.0/) applies to the data made available in this article, unless otherwise stated. 
(Continued from previous page)

Trial registration: The trial was registered at the German Clinical Trials Register (9 January 2015, Identifier: DRKS00007666).

Keywords: Lunch provision, Staff canteen, Garment factory, Cambodia, Randomized controlled trial, Malnutrition, Underweight, Anemia, Micronutrient deficiency, Industrial worker

\section{Background}

More than 600 export-oriented garment factories operate in Cambodia, which demonstrates the key role that this industry plays in the country's economy [1]. Almost $90 \%$ of their 600,000 employees are female, mainly young women who migrate from disadvantaged lowincome rural households [2-4]. Located in and around Phnom Penh, the capital of Cambodia, factories are usually owned by foreign investors $[1,5,6]$. They implement low value-added activities and rely on inexpensive labor $[5,6]$. The 2017 minimum wage for Cambodian garment workers amounted to $153 \mathrm{USD} /$ month, which was notably lower in previous years [1]. This fact inevitably drives workers to depend on bonuses and overtime work $[3,7,8]$, and yet more than $50 \%$ of the total salary is budgeted to support family members $[3,4,7,8]$.

Socio-economic surveys have concluded that an appropriate diet is likely to be out of reach $[3,7,8]$. It is reported that workers spend on average $\sim 1.5 \mathrm{USD} /$ day on food, primarily at food stalls close to the factories, and that saving measures involve skipping of meals [3, 7, 8]. Despite the importance of the topic, sound data regarding the dietary intake of Cambodian garment workers are missing. Based on a small cross-sectional survey, NGOs reported a prevalence of 36\% underweight among female workers [3]. On the other hand, a study conducted by the ILO in several factories found 14\% of workers to be underweight and $45 \%$ to be anemic [9]. Finally, the authors reported on 31\% underweight, 27\% anemia, and a high prevalence of poor iron status (data from the present factory-based study) [4].

Malnutrition of women in reproductive age (with respect to underweight, anemia, and micronutrient deficiencies) is one of the great threats to public health in the country [10]. For instance, during gestation, malnutrition is linked to increased maternal morbidity and mortality, fetal and neonatal deaths, premature delivery, and low birth weight [11-13]. Anemia of nutritional origin is caused by poor diets that lack adequate amounts of iron, vitamin A (VitA), vitamin B12 (VitB12), and/or folate $[11,14]$. In contrast, non-nutritional factors are especially hemoglobinopathies, menstrual blood loss, and parasite infestation $[11,15,16]$.

The implementation of canteens serving lunch in Cambodian garment factories has been proposed as an adequate intervention to improve the nutritional situation of workers, to reduce morbidity and absenteeism, and thereby to increase productivity [17]. Nevertheless, convincing trials that verify these hypotheses are rare and the vast majority of factories does not hold a canteen, with the operation costs being the most critical factor for factory owners [17]. Despite the implementation of a first on-topic survey by the ILO [9], detailed insights are missing concerning the consequences of lunch provision on the nutritional and health status of Cambodian garment workers. Yet, this knowledge is essential to make informed choices on the setup and operation of staff canteens.

The current essay reports on the main outcomes of the LUPROGAR study (Lunch Provision in Garment Factories), a factory-based exploratory randomized controlled trial, whose objective is to determine the effect of a lowprice model lunch provision via a canteen during workdays on anthropometry, as well as on the hemoglobin (Hb) and micronutrient status of female garment workers in Cambodia. Prior to this paper, the authors provided detailed information on the participants' nutritional and health status at baseline [4], the low-price model lunch provision approach within this trial [18], and on the food consumption of study participants with and without access to the model lunch provision [19].

\section{Methods}

\section{Study design and setting}

LUPROGAR was a factory-based exploratory randomized controlled trial (two-group, 1:1 ratio, parallel), planned for a six-month period. The study was realized during 2015 at Apsara Garment Co. Ltd., an exportoriented garment factory in the commune Chom Chau in Phnom Penh. The vast majority of the $1300 \mathrm{em}$ ployees were young women from low-income rural households. Working conditions, including six workdays per week, were assumed to match the overall conditions of employment in this industry. Apsara Garment Co. Ltd. was selected purposely, since the factory management showed interest in cooperating in this project.

\section{Participants}

The study population included young non-pregnant nulliparous women employed by Apsara Garment Co. Ltd., 
intended to match the characteristics of the majority of Cambodian garment workers. To be eligible, women had to meet the inclusion criteria and provide written informed consent before enrollment. The inclusion criteria were: being nulliparous (to rule out any confounding from breastfeeding and/or recent pregnancy), nonpregnant, apparently healthy, and $<31$ years old at the date of enrollment. The criteria for exclusion were: acute or chronic disease requiring treatment and/or medication (including $\mathrm{Hb}$ concentration $<7.0 \mathrm{~g} / \mathrm{dL}$ and clinical signs of VitA- or iodine deficiency), handicaps impairing nutritional and/or health status, and employment as supervisor. Subjects excluded due to any health problem were referred for treatment.

Beginning of March 2015, the factory management and union representatives were briefed about the LUPROGAR trial. Following this, the study was declared during a meeting to all workers. Trained assistants obtained written informed consents at an information desk at lunch breaks and at the end of working days (mid of March till beginning of April 2015). Women were then invited to the enrollment and baseline assessment which was performed during working hours, including a clinical check-up by trained nurses (end of April 2015).

\section{Intervention}

A temporary canteen was installed in a roofed outdoor area at the factory site [18]. Apsara Garment Co. Ltd. had never operated a staff canteen before. Within the LUPROGAR trial, it was envisaged to serve adequate full lunch sets (consisting of a stir-fried dish, a soup, a side item (cooked rice), and a fruit dessert) at reasonable costs ( $1 \mathrm{USD} /$ person/day) in collaboration with Hagar Catering and Facilities Management Ltd., an established Phnom Penh-based canteen service provider. Sets should provide about one third of the recommended dietary allowance (RDA) for non-pregnant women aged 19-30 years old (total $\sim 700 \mathrm{kcal}$ ) [20]. Based on these standards, a biweekly menu (of 12 model lunch sets) was outlined in consultation with the caterer [18]. Focus was laid on accepted Cambodian dishes, using local foods and ensuring variety by providing cereals, various vegetables, animal source foods (meat or fish), and fresh fruits on a daily basis.

Following the enrollment and baseline assessment at the end of April 2015, daily free lunch provision on workdays for the intervention group was carried out by the caterer for 6 months from beginning of May until end of October 2015. Dishes were prepared according to consistent recipes at a professional kitchen located in Phnom Penh's city center and delivered within $1 \mathrm{~h}$. Stirfried and soup dishes were reheated just before serving and the canteen staff was instructed to serve constant portion sizes. At the canteen, participants had free access to drinking water and locally used condiments (non-fortified soy/fish sauce and fresh red chili). After 1 month, the initial menu was slightly adjusted according to preferences expressed by workers via a short preference questionnaire. Access to the canteen was voluntary and recorded daily by an assistant. Table 1 presents the estimated nutritive value of the lunch sets. Further information on exact costs, components and ingredients, serving sizes, and corresponding nutritive value of single lunch sets can be found elsewhere [18].

\section{Outcomes}

Given the exploratory trial design, the outcomes were planned as changes in body mass index (BMI, $\mathrm{kg} / \mathrm{m}^{2}$ ), weight $(\mathrm{kg})$, triceps skinfold thickness (TSF, $\mathrm{mm}$ ), and mid upper-arm muscle circumference (MUAMC, $\mathrm{cm}$ ) (as anthropometric variables), as well as changes in $\mathrm{Hb}(\mathrm{g} / \mathrm{dL})$ and serum ferritin (FER, $\mu \mathrm{g} / \mathrm{L}$, inflammation-adjusted), soluble transferrin receptor (sTfR, mg/L), retinol binding protein (RBP, $\mu \mathrm{mol} / \mathrm{L}$, inflammation-adjusted), folate (ng/ $\mathrm{mL}$ ), and VitB12 concentrations (pmol/L) (as $\mathrm{Hb}$ and micronutrient status) of participants at follow-up (planned at 6 months).

\section{Data collection}

Details regarding the questionnaires, anthropometric measurements, and the blood sample collection and analysis can be found in a previous publication [4]. In brief, trained assistants applied a pre-tested socio-economic

Table 1 Estimated nutritive value of the low-price model lunch sets provided to female garment workers at a factory in Phnom Penh, Cambodia ${ }^{a}$

\begin{tabular}{|c|c|c|c|}
\hline Nutritive value ${ }^{b}$ & Mean & Min. & Max. \\
\hline Energy, kcal (\% of RDA) & $697(33)$ & $591(28)$ & $793(38)$ \\
\hline Carbohydrates, g (\% of RDA) & $107(37)$ & $100(34)$ & $123(42)$ \\
\hline Protein, g (\% of RDA) & $23(46)$ & $16(32)$ & $30(60)$ \\
\hline Fat, g (\% of RDA) & $18(34)$ & $12(23)$ & $24(45)$ \\
\hline Dietary fiber, g (\% of Al) & $8(32)$ & $6(24)$ & $12(48)$ \\
\hline Vitamin C, mg (\% of RDA) & $111(159)$ & $24(34)$ & $212(303)$ \\
\hline Iron, mg (\% of RDA) & $6(20)$ & $4(14)$ & $12(41)$ \\
\hline Vitamin A, $\mu \mathrm{g}$ RAE (\% of RDA) & $331(66)$ & $61(12)$ & $799(160)$ \\
\hline Folate, $\mu \mathrm{g}(\%$ of RDA) & $175(44)$ & $29(7)$ & $477(120)$ \\
\hline Vitamin B12, $\mu \mathrm{g}$ (\% of RDA) & $0.7(29)$ & $0.2(8)$ & $1.5(63)$ \\
\hline
\end{tabular}

${ }^{a}$ Among 12 various lunch sets (composed of stir-fry, soup, side item (cooked rice), and fruit dessert) provided over a biweekly rotating cycle (one set per day, at six workdays per week). Data from a preceding publication including detailed information on the biweekly menu, costs, ingredients, serving sizes, and estimated individual nutritive values [18]

${ }^{\mathrm{b}}$ Following recommendations for non-pregnant women aged 19-30 years old from various sources: energy, protein (adjusted for $80 \%$ protein quality), vitamin C, iron (adjusted for $10 \%$ bioavailability), vitamin A, and folate [20]; carbohydrates [21]; fat and vitamin B12 [22]; and dietary fiber [23] Min Minimum, Max Maximum, $\mathrm{kcal}$ Kilocalories, RDA Recommended dietary allowance, $A$ l Adequate intake, $R A E$ Retinol activity equivalent 
status questionnaire at baseline. In the context of the clinical screening, trained nurses administered a pretested health questionnaire (baseline and follow-up). Weight, height, TSF, and mid-upper arm circumference (MUAC) were assessed by two trained assistants following CDC guidelines [24] (baseline and follow-up). All devices and measurement procedures were pre-tested under field conditions. Weight was measured to the nearest $0.1 \mathrm{~kg}$, height to the nearest $0.1 \mathrm{~cm}$, TSF to the nearest $0.2 \mathrm{~mm}$ (using a Tanner/Whitehouse caliper (Holtain Ltd., UK)), and MUAC to the nearest $0.1 \mathrm{~cm}$. All measurements were taken twice and the mean was used for further analysis. Subjects were classified using defined BMI cut-off points [24]. Within normal weight subjects, a BMI between 18.5 and $20.0 \mathrm{~kg} / \mathrm{m}^{2}$ was also designated as "low-normal BMI" [25]. MUAMC was calculated using the following equation [26]:

$$
\mathrm{MUAMC}=\mathrm{MUAC}-(\pi \mathrm{x} \text { TSF })
$$

Samples of non-fasting venous blood were taken by trained nurses (baseline and follow-up). Blood drops were put on a glass slide for subsequent twofold blood $\mathrm{Hb}$ measurement using a HemoCue $\mathrm{Hb} 301$ photometer (HemoCue AB, Sweden). The mean was used in further analysis. Blood left in the syringe was then processed to obtain serum aliquots, which were kept frozen at $-25^{\circ} \mathrm{C}$ [4] . Serum VitB12 was measured by electrochemiluminescence at the Pasteur Institute Cambodia (Phnom Penh, Cambodia), using a COBAS e 411 immunoassay analyzer (Roche Diagnostics, Switzerland). When analyzing follow-up subsamples, VitB12 results of controls and samples unexpectedly fell out of the certified ranges. Therefore, only baseline results on VitB12 are shown here. Remaining aliquots were shipped on dry ice to the Institute of Nutritional Sciences at the Justus Liebig University Giessen (Germany) and stored at $-25^{\circ} \mathrm{C}$ until they were processed at the VitMin laboratory (Willstaett, Germany). FER, sTfR, RBP, C-reactive protein (CRP, mg/L), and $\alpha 1$-acidglycoprotein (AGP, g/L) were determined by a sandwich enzyme-linked immunosorbent assay (ELISA) technique [27]. Serum folate was measured via a microbiological assay by using chloramphenicol-resistant Lactobacillus rhamnosus [28]. Both methods used pooled samples for quality control and certified samples (CDC, USA and Bio-Rad, USA) to establish calibration curves for each indicator. All values represent the mean of an independent double measurement. For folate, the maximum tolerated difference between duplicate measurements was $+/-40 \%$, otherwise the result was not included in further analysis.

Anemia was defined according to established cut-offs [11]. Subclinical inflammation was defined as increased CRP (>5 mg/L) and/or increased AGP concentrations $(>1 \mathrm{~g} / \mathrm{L})$, and categorized into three stages [29]. FER concentration was adjusted for inflammation by correction factors for each inflammation stage [29]. Iron deficiency was defined by depleted iron stores (adjusted serum FER $<15 \mu \mathrm{g} / \mathrm{L}$ ) [11], marginal iron stores by adjusted serum FER $\geq 15$ and $<50 \mu \mathrm{g} / \mathrm{L}$ [30], tissue iron deficiency by high serum sTfR (>8.3 $\mathrm{mg} / \mathrm{L}$ ) [31], and iron deficiency anemia by $\mathrm{Hb}<12.0 \mathrm{~g} / \mathrm{dL}$ and simultaneous adjusted serum FER $<15 \mu \mathrm{g} / \mathrm{L}$ [11]. Serum RBP concentrations were used as a surrogate measure for circulating retinol to evaluate VitA status [32]. RBP values were likewise adjusted for the presence of inflammation by correction factors for each stage of inflammation [33]. VitA deficiency was defined by adjusted serum RBP < $0.70 \mu \mathrm{mol} / \mathrm{L}$ and marginal VitA deficiency by adjusted serum RBP values $\geq 0.70$ and $<1.05 \mu \mathrm{mol} / \mathrm{L}[32,34]$. Folate deficiency was defined by serum folate $<3 \mathrm{ng} / \mathrm{mL}$ and marginal deficiency by serum folate $\geq 3$ and $<6 \mathrm{ng} /$ $\mathrm{mL}$ [35]. VitB12 deficiency was defined as serum VitB1 $2<148 \mathrm{pmol} / \mathrm{L}$ and a marginal VitB12 deficiency as serum VitB12 $\geq 148$ and $<222 \mathrm{pmol} / \mathrm{L}$ [36].

\section{Sample size}

An explorative strategy was used to determine an appropriate sample size, since both, data on the nutritional status of Cambodian garment workers and data on the effects of lunch provision in this context were largely missing at time of trial implementation. G*Power (v.3.1.9.2, University of Kiel, Germany) was used to carry out the calculation. At a two-tailed 5\% level of significance (alpha $=0.05$ ) and a statistical power of $80 \%$ (beta $=0.20)$ to detect a small to medium standardized effect size of 0.35 (Cohen's $d$ ) between both arms [37], 130 subjects in each group were required at follow-up. Considering a $20 \%$ loss to follow up, it was aimed at recruiting a total of 330 participants (165 subjects in each arm).

\section{Randomization}

Simple randomization with a 1:1 ratio into an intervention arm (access to six-month lunch provision through local canteen during workdays) and a control arm (equal monetary compensation at the end of the trial) was conducted via assigning a computer-generated random number for each subject (identifying the allocation to intervention or control) by making use of the random number generator within SPSS (v.22.0.0.1, IBM Corp., USA) (prepared by study coordinator). Enrolled participants were individually assigned to groups by an assistant who was neither involved in the enrollment procedure nor in the assessments.

\section{Statistical analysis}

Data of questionnaires and anthropometry sheets were double-entered by trained assistants using EpiData (v.3.1, 
EpiData Association, Denmark). Overall data management and statistical analyses were executed using SPSS (v.22.0.0.1, IBM Corp., USA). Evaluation only included participants who completed the follow-up, regardless of the actual individual adherence of intervention subjects to daily eating lunch at the staff canteen. Detailed baseline findings among all originally enrolled subjects can be found in a previously published paper [4]. A wealth index was computed to assess the socio-economic status of subjects' households using principal component analysis [38]. The index was based on the following variables: number of rooms per household, people per room, main place of cooking, main type of fuel, main material of the floor, and ownership of a bank account, latrine, electricity, and several household assets (radio, television, non-mobile telephone, wardrobe, sewing machine, DVD player, generator, watch, motorcycle, motorcycle cart, car, and boat). Baseline background characteristics of the groups were summarized by using descriptive statistics.

In the primary analysis, a general linear model with adjustments for baseline values (covariates) was used to calculate marginal means per group with 95\% CIs for each outcome variable at follow-up, as well as to estimate the intervention effects as marginal mean differences with 95\% CIs and corresponding effect sizes (Cohen's $d$ ). The significance was set at 5\% ( $p$-value < $0.05)$. In a secondary analysis, the same model was used to compute marginal mean changes with $95 \%$ CIs per group for each outcome variable within following subsets (based on the assumption that changes differ according to baseline status): for anthropometric variables, subgroups were underweight, low-normal BMI, and BMI $\geq 20.0 \mathrm{~kg} / \mathrm{m}^{2}$ at baseline; for $\mathrm{Hb}$, subgroups were moderate anemia, mild anemia, and not anemic at baseline; for FER and sTfR, subgroups were iron deficiency, marginal iron stores, and sufficient iron stores at baseline; for RBP, subgroups were marginal VitA deficiency and no VitA deficiency at baseline; and for folate, subgroups were marginal folate deficiency and no folate deficiency at baseline. Given the small sample sizes within subgroups, this secondary analysis was not suited to test for powerful statistical significance.

\section{Changes to procedure}

Due to a relatively high number of participants who ceased to work and left the factory (primarily as a result of a change of the main purchaser and a great part of management), the follow-up was antedated by 1 month in order to minimize the number of further dropouts. Hence, the endline assessment was conducted after 5 months (beginning of October 2015) instead of after 6 months. The canteen operated as planned until end of October 2015.

\section{Results}

Baseline characteristics

Between 14 March and 4 April 2015, a total of 267 female workers signed the informed consent prior to enrollment (Fig. 1). At the enrollment procedure, which took place from 21 to 29 April 2015, 229 workers were present whereas 38 were not $(n=30$ ceased to work and $n=8$ refused to participate). Further six workers were excluded from participation at the clinical screening ( $n=2$ with $\mathrm{Hb}<7.0 \mathrm{~g} / \mathrm{dL}, n=2$ not nulliparous, $n=1$ with physical handicap, and $n=1$ with chronic disease). The remaining 223 women were randomly assigned and access to free lunch provision for the intervention group started in early May 2015.

The follow-up assessment took place from 1 to 10 October 2015. One hundred seventy-two women (77\%) completed the follow-up ( $n=50$ ceased to work and $n=$ 1 became pregnant), with endline data available for anthropometry. Dropouts were equally distributed across groups. The count of incomplete blood values for both time points (due to refused blood sampling, missing aliquot, or deviating duplicate measurement) was low for $\mathrm{Hb}(n=2$ of 172$)$, FER, sTfR, RBP, CRP, and AGP (all $n=4$ of 172), but slightly higher for folate $(n=21$ of 172). Follow-up values for VitB12 were not available as described in the Methods section. Within the actual intervention period of 5 months, intervention subjects on average (mean) visited the staff canteen on $85 \%$ of total days (median was 92\%).

Overall, participants had a mean \pm SD age of $21 \pm 3$ years and a total monthly salary of $195 \pm 34$ USD. Of the total, $94 \%$ were single ( $n=162$ of 172$), 67 \%$ stayed at a nearby shared room for rent $(n=115$ of 172$)$, and $63 \%$ $(n=109$ of 172$)$ worked as sewer. $63 \%(n=108$ of 172$)$ reported a preceding employment in another garment factory. Baseline equivalence in background characteristics amongst groups was given (Table 2), despite a $23 \%$ dropout.

Data on the nutritional status and prevalence rates of anemia and micronutrient deficiencies are summarized in Table 3. At baseline, the prevalence of subclinical inflammation was $1 \%(n=1$ of $168(n=1$ control $)$ ) for incubation (CRP $>5 \mathrm{mg} / \mathrm{L}$ only), $1 \%(n=1$ of $168(n=1$ control)) for early convalescence (AGP $>1 \mathrm{~g} / \mathrm{L}$ and CRP $>5 \mathrm{mg} / \mathrm{L})$, and $7 \%(n=12$ of $168(n=4$ intervention and $n=8$ control)) for late convalescence (AGP $>1 \mathrm{~g} / \mathrm{L}$ only). At 5 months, the prevalence was $1 \%$ for incubation $(n=$ 1 of $171(n=1$ control $)), 1 \%$ for early convalescence $(n=$ 2 of $171(n=2$ control)), and 6\% ( $n=11$ of $171 \quad(n=7$ intervention and $n=4$ control)) for late convalescence. Mean values at baseline for outcome measures are included in Tables 4 and 5 . No significant differences between groups were noticed for anthropometric variables and concentrations of $\mathrm{Hb}, \mathrm{FER}$, sTfR, and folate. 


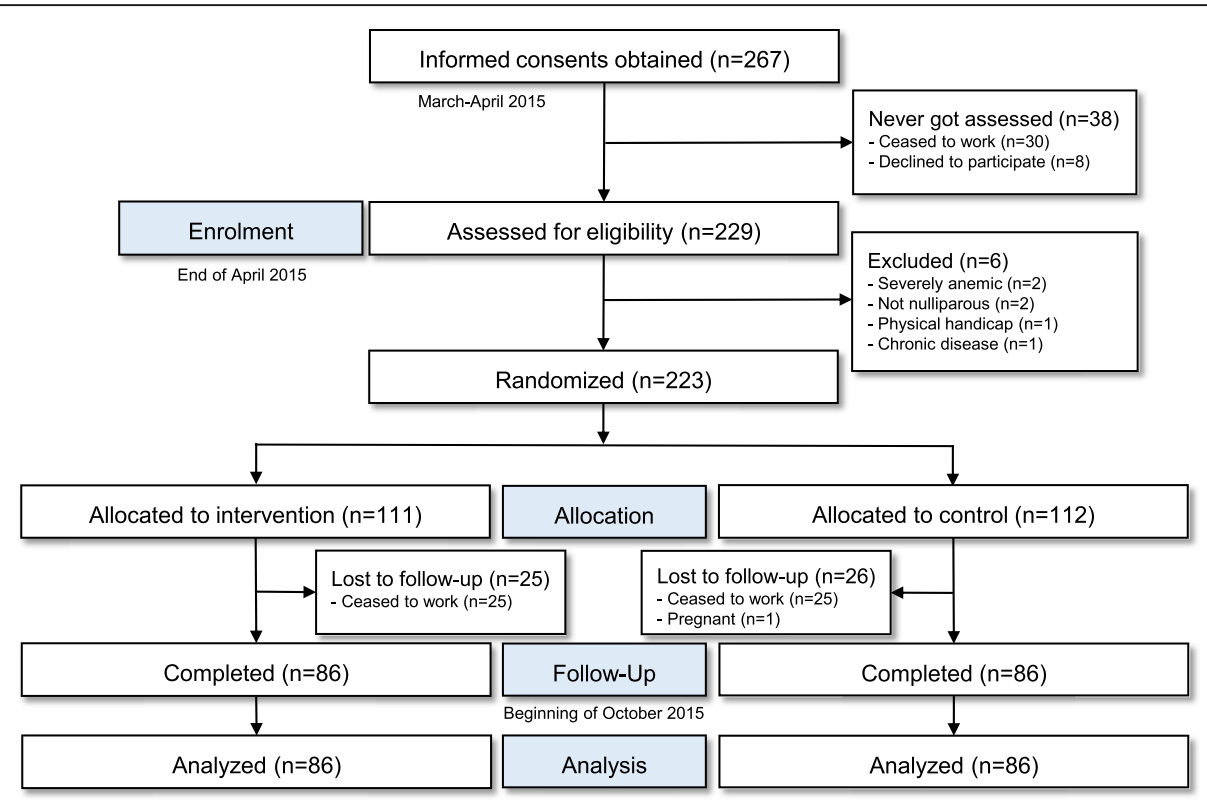

Fig. 1 CONSORT flow diagram of the trial. The intervention group had access to free lunch provision on workdays through a canteen for 5 months.

Although, mean RBP concentration was somewhat higher among control subjects $(1.49 \pm 0.31$ vs. $1.37 \pm$ $0.26 \mu \mathrm{mol} / \mathrm{L})$.

\section{Intervention effects on anthropometric variables}

The adjusted mean BMI at 5 months was $0.1 \mathrm{~kg} / \mathrm{m}^{2}$ higher among the intervention group, representing a nonsignificant, very small to small effect $(p=0.27$, Cohen's $d=0.17$ ). On the other hand, no considerable differences were observed between groups for adjusted mean weight. The adjusted mean TSF among the intervention group was higher by $0.4 \mathrm{~mm}$, also illustrating a non-significant, very small to small effect ( $p=0.24$, Cohen's $d=0.18$ ). In contrast, adjusted mean MUAMC at 5 months was slightly lower, but not significantly, by $0.1 \mathrm{~cm}(p=0.35$, Cohen's $d=-0.14$ ) (Table 4). Unadjusted values generally did not deviate from results obtained by adjustment for baseline values (only the unadjusted impact on weight was slightly higher with $+0.2 \mathrm{~kg}$ ).

Subgroup analysis showed that adjusted means of BMI, weight, TSF, and MUAMC among underweight participants $\left(B M I<18.5 \mathrm{~kg} / \mathrm{m}^{2}\right)$ increased in intervention as well as in control subjects, with minor differences observed between groups only for BMI (around + $0.4 \mathrm{~kg} / \mathrm{m}^{2}$ vs. $+0.2 \mathrm{~kg} / \mathrm{m}^{2}$ ) and weight (about $+1.0 \mathrm{~kg}$ vs. $+0.6 \mathrm{~kg}$ ). Differences were also found in participants with low-normal BMI at baseline (BMI $\geq 18.5$ and $<20$ $\left.\mathrm{kg} / \mathrm{m}^{2}\right)$. Here, the adjusted mean BMI at follow-up was higher by around $0.35 \mathrm{~kg} / \mathrm{m}^{2}$ in the intervention group (around $+0.3 \mathrm{~kg} / \mathrm{m}^{2}$ vs. $-0.05 \mathrm{~kg} / \mathrm{m}^{2}$ ). Mean weight was likewise higher by approximately $0.4 \mathrm{~kg}$ (around $+0.7 \mathrm{~kg}$ vs. $+0.3 \mathrm{~kg}$ ), as well as mean TSF by $0.5 \mathrm{~mm}$ (around + 0.2 vs. $-0.3 \mathrm{~mm}$ ). On the other hand, the adjusted mean MUAMC was slightly lower by around $0.2 \mathrm{~cm}$ in intervention participants. Furthermore, in workers with a BMI $\geq 20 \mathrm{~kg} / \mathrm{m}^{2}$, mean BMI and mean weight marginally decreased in both groups, with no differences noticed. Adjusted mean TSF at 5 months was slightly higher by $0.5 \mathrm{~mm}$ (around $+0.1 \mathrm{~mm}$ vs. $-0.4 \mathrm{~mm}$ ), while mean MUAMC was marginally lower by approximately $0.1 \mathrm{~cm}$ in the intervention group (Fig. 2).

\section{Intervention effects on hemoglobin and micronutrient status}

At the end of the intervention (Table 5), the adjusted mean $\mathrm{Hb}$ was $0.1 \mathrm{~g} / \mathrm{dL}$ higher among the intervention group, a non-significant, very small to small effect ( $p=$ 0.30 , Cohen's $d=0.17$ ). In contrast, mean FER was lower by $6.6 \mu \mathrm{g} / \mathrm{L}$, illustrating a significant, small to medium negative effect $(p=0.015$, Cohen's $d=-0.39)$. Concurrently, mean sTfR was $0.2 \mathrm{mg} / \mathrm{L}$ higher, representing a non-significant, small negative effect ( $p=0.15$, Cohen's $d=0.22$ ). Apart from that, the adjusted mean RBP was $0.05 \mu \mathrm{mol} / \mathrm{L}$ higher among the intervention group, a non-significant, very small to small difference $(p=0.27$, Cohen's $d=0.17$ ). At last, mean folate was higher by 1.1 $\mathrm{ng} / \mathrm{mL}$, outlining a non-significant, small to medium positive impact ( $p=0.054$, Cohen's $d=0.32$ ).

In the secondary subgroup analysis (Fig. 3), mean change in $\mathrm{Hb}$ differed only among the few women with moderate anemia $(\mathrm{Hb} \geq 8.0$ and $<11.0 \mathrm{~g} / \mathrm{dL})$ at baseline. Here, the adjusted mean $\mathrm{Hb}$ at 5 months was higher by 
Table 2 Baseline background characteristics of female Cambodian garment workers with completed follow-up by group $^{a}$

\begin{tabular}{|c|c|c|}
\hline & \multicolumn{2}{|l|}{ Group } \\
\hline & Intervention & Control \\
\hline Total, $n(\%)$ & $86(50)$ & $86(50)$ \\
\hline Age, years & $21 \pm 3^{b}$ & $21 \pm 3$ \\
\hline Weight, kg & $46 \pm 6$ & $47 \pm 6$ \\
\hline Height, cm & $153 \pm 5$ & $154 \pm 6$ \\
\hline School attendance, years & $7 \pm 2$ & $7 \pm 2$ \\
\hline \multicolumn{3}{|l|}{ Marital status, $n(\%)$} \\
\hline Single & $81(94)$ & $81(94)$ \\
\hline Married & $4(5)$ & $4(5)$ \\
\hline Widowed & $1(1)$ & $1(1)$ \\
\hline \multicolumn{3}{|l|}{ Hometown province, $n(\%)$} \\
\hline Phnom Penh & $2(2)$ & $5(6)$ \\
\hline Others & $84(98)$ & $81(94)$ \\
\hline Duration of employment in factory, months & $14 \pm 9$ & $13 \pm 9$ \\
\hline Monthly basic salary, USD & $131 \pm 14$ & $131 \pm 9$ \\
\hline $\begin{array}{l}\text { Last monthly salary (incl. bonus, overtime, and } \\
\text { allowance), USD }\end{array}$ & $198 \pm 37$ & $\begin{array}{l}191 \pm \\
31^{c}\end{array}$ \\
\hline \multicolumn{3}{|l|}{ Job type in factory, $n(\%)$} \\
\hline Sewing & $52(60)$ & $57(66)$ \\
\hline Quality control & $16(19)$ & $12(14)$ \\
\hline Buttoning & $8(9)$ & $4(5)$ \\
\hline Cutting & $4(5)$ & $3(3)$ \\
\hline Packaging & $3(3)$ & $3(3)$ \\
\hline Others & $3(3)$ & $7(8)$ \\
\hline \multicolumn{3}{|l|}{ Accommodation on workdays, $n(\%)$} \\
\hline Hometown, family household & $18(21)$ & $32(37)$ \\
\hline Nearby place of friend/family & $4(5)$ & $1(1)$ \\
\hline Nearby shared room for rent & $63(73)$ & $52(60)$ \\
\hline Nearby private room for rent & $1(1)$ & $1(1)$ \\
\hline Number of people in family household & $4.6 \pm 1.4$ & $5.2 \pm 1.6$ \\
\hline Wealth index of family household & $1.9 \pm 2.8$ & $2.4 \pm 3.6$ \\
\hline Participant's monthly payment to family household, USD & $119 \pm 39$ & $\frac{122 \pm}{41^{d}}$ \\
\hline \multicolumn{3}{|l|}{ Family household's primary source of income, $n(\%)$} \\
\hline Wage employment & $46(53)$ & $54(63)$ \\
\hline Farming & $22(26)$ & $17(20)$ \\
\hline Casual labor & $6(7)$ & $10(12)$ \\
\hline Business/petty trade & $7(8)$ & $4(5)$ \\
\hline Others & $5(6)$ & $1(1)$ \\
\hline
\end{tabular}

USD United States Dollar

${ }^{\mathrm{a}}$ Total $n=172$

${ }^{\mathrm{b}}$ Mean \pm SD (all such values)

${ }^{c} n=82$ ( $n=4$ newcomer ( $\leq 1$ month of employment) without previous monthly salary from this factory)

${ }^{d} n=85$ ( $n=1$ participant without monthly payment to family household)

$0.8 \mathrm{~g} / \mathrm{dL}$ in intervention participants (around $+0.6 \mathrm{~g} / \mathrm{dL}$ vs. $-0.2 \mathrm{~g} / \mathrm{dL})$. Overall, mean $\mathrm{Hb}$ slightly increased among the subjects with mild anemia $(\mathrm{Hb} \geq 11.0$ and $<$
$12.0 \mathrm{~g} / \mathrm{dL}$ ), and marginally decreased for women not affected by anemia $(\mathrm{Hb} \geq 12.0 \mathrm{~g} / \mathrm{dL})$. Mean FER slightly increased, for both groups, among workers affected by iron deficiency (FER $<15 \mu \mathrm{g} / \mathrm{L})$, as well as among the subjects with marginal iron stores (FER $\geq 15$ and $<50 \mu \mathrm{g}$ / L). However, among women with marginal iron stores, sTfR was higher by $0.4 \mathrm{mg} / \mathrm{L}$ in intervention participants (around $+0.1 \mathrm{mg} / \mathrm{L}$ vs. $-0.3 \mathrm{mg} / \mathrm{L}$ ). On the other hand, mean change in FER clearly differed among groups in subjects with sufficient iron stores (FER $\geq 50 \mu \mathrm{g} / \mathrm{L}$ ) at baseline. Here, mean FER at follow-up was lower by $18 \mu \mathrm{g} / \mathrm{L}$ in the intervention participants. In line with this finding, mean sTfR at 5 months was higher by $0.3 \mathrm{mg} / \mathrm{L}$ in intervention participants (around $+0.2 \mathrm{mg} / \mathrm{L}$ vs. -0.1 $\mathrm{mg} / \mathrm{L})$. The adjusted mean change in RBP differed only among the few women with marginal VitA deficiency $(\mathrm{RBP} \geq 0.70$ and $<1.05 \mu \mathrm{mol} / \mathrm{L})$ at baseline. Mean RBP at follow-up was higher by approximately $0.2 \mu \mathrm{mol} / \mathrm{L}$ in intervention participants. Mean folate considerably increased, for both groups, among workers affected by marginal folate deficiency (folate $\geq 3$ and $<6 \mathrm{ng} / \mathrm{mL}$ ), and was higher by $0.7 \mathrm{ng} / \mathrm{mL}$ in intervention participants (around $+2.2 \mathrm{ng} / \mathrm{mL}$ vs. $+1.5 \mathrm{ng} / \mathrm{mL}$ ). Mean change also clearly differed between groups in subjects not affected by folate deficiency (folate $\geq 6 \mathrm{ng} / \mathrm{mL}$ ), where folate at 5 months was higher by $1.2 \mathrm{ng} / \mathrm{mL}$ for intervention participants $(+1.4 \mathrm{ng} / \mathrm{mL}$ compared with $+0.2 \mathrm{ng} / \mathrm{mL})$.

\section{Discussion}

This model lunch provision for 5 months resulted in marginally increased mean BMI, mean weight, mean TSF, and a nominal lower mean MUAMC. These insignificant results, illustrating negligible to very small/small effects, are assumed to represent, if any, a very limited general impact on worker's anthropometry. But, subgroup analysis suggests a more pronounced intervention impact on weight (around $+0.4 \mathrm{~kg}$ ) and BMI (up to + $0.35 \mathrm{~kg} / \mathrm{m}^{2}$ ) among underweight participants and those with a low-normal BMI. Furthermore, in subjects with low-normal BMI and those with a BMI $\geq 20 \mathrm{~kg} / \mathrm{m}^{2}$, TSF was thicker by $0.5 \mathrm{~mm}$. Although not being suited to test for statistical significance, such effects would actually correspond to small to medium effects (Cohen's $d$ between $\geq 0.2$ and $<0.5$ ).

Food provision trials in low-income countries primarily focus on school feeding programs. Interestingly, evidence of the impact on anthropometric indices remains inconclusive [39]. In Cambodia, the recent ILO multifactory study reported that 1 year of daily food provision did not induce changes of the mean BMI of Cambodian garment workers [9]. However, food provision within the ILO study differed substantially in its intervention factories (ranging from snacks to full lunches). Therefore, comparisons are difficult to draw. Moreover, ILO-study 
Table 3 Nutritional status, anemia, and micronutrient deficiencies at baseline and 5 months (follow-up) in female Cambodian garment workers by group ${ }^{a}$

\begin{tabular}{ll} 
Group & \\
\cline { 2 - 3 } Intervention & Control \\
\hline
\end{tabular}

Underweight $^{\mathrm{b}}\left(\mathrm{BMl}<18.5 \mathrm{~kg} / \mathrm{m}^{2}\right)$

$\begin{array}{lll}\text { Baseline } & 29 / 86(34) & 25 / 86(29) \\ \text { At } 5 \text { months } & 25 / 86(29) & 23 / 86(27)\end{array}$

Normal $^{\mathrm{C}}\left(\mathrm{BMI} \geq 18.5\right.$ and $<25.0 \mathrm{~kg} / \mathrm{m}^{2}$ )

$\begin{array}{lll}\text { Baseline } & 54 / 86(63) & 58 / 86(67) \\ \text { At } 5 \text { months } & 57 / 86(66) & 60 / 86(70)\end{array}$

Overweight (BMI $\geq 25.0$ and $<30.0 \mathrm{~kg} / \mathrm{m}^{2}$ )

$\begin{array}{lll}\text { Baseline } & 3 / 86(3) & 3 / 86(3) \\ \text { At } 5 \text { months } & 4 / 86(5) & 3 / 86(3) \\ \text { Anemia }^{\text {d, e }}(\mathrm{Hb}<12.0 \mathrm{~g} / \mathrm{dL}) & & \\ \text { Baseline } & 19 / 85(22) & 23 / 85(27) \\ \text { At } 5 \text { months } & 19 / 85(22) & 22 / 86(26)\end{array}$

Iron deficiency ${ }^{\mathrm{f}}\left(\mathrm{FER}^{\mathrm{g}}<15 \mu \mathrm{g} / \mathrm{L}\right)$

$\begin{array}{lll}\text { Baseline } & 15 / 84(18) & 21 / 84(25) \\ \text { At } 5 \text { months } & 17 / 85(20) & 13 / 86(15)\end{array}$

Marginal iron stores ${ }^{f}\left(\mathrm{FER}^{\mathrm{g}} \geq 15\right.$ and $\left.<50 \mu \mathrm{g} / \mathrm{L}\right)$

$\begin{array}{lll}\text { Baseline } & 49 / 84(58) & 35 / 84(42) \\ \text { At } 5 \text { months } & 48 / 85(56) & 46 / 86(54)\end{array}$

Tissue iron deficiency ${ }^{f}(\mathrm{sTfR}>8.3 \mathrm{mg} / \mathrm{L})$

$\begin{array}{lcc}\text { Baseline } & 7 / 84(8) & 10 / 84(12) \\ \text { At } 5 \text { months } & 5 / 85(6) & 11 / 86(13) \\ \text { ron deficiency anemia }^{\mathrm{f}}\left(\mathrm{Hb}<12.0 \mathrm{~g} / \mathrm{dL}^{2} \text { and } \mathrm{FER}^{\mathrm{g}}<15 \mu \mathrm{g} / \mathrm{L}\right) \\ \text { Baseline } & 8 / 84(10) & 12 / 84(14) \\ \text { At } 5 \text { months } & 8 / 85(9) & 9 / 86(10)\end{array}$

Vitamin A deficiency ${ }^{\mathrm{f}}\left(\mathrm{RBP}^{\mathrm{g}}<0.70 \mu \mathrm{mol} / \mathrm{L}\right)$

Baseline $\quad 0 / 84(0) \quad 0 / 84(0)$

At 5 months $\quad 0 / 85(0) \quad 0 / 86(0)$

Marginal vitamin A deficiency ${ }^{\mathrm{f}}\left(\mathrm{RBP}^{\mathrm{g}} \geq 0.70\right.$ and $\left.<1.05 \mu \mathrm{mol} / \mathrm{L}\right)$

$\begin{array}{lll}\text { Baseline } & 7 / 84(8) & 3 / 84(4) \\ \text { At } 5 \text { months } & 8 / 85(9) & 7 / 86(8)\end{array}$

Folate deficiency ${ }^{\mathrm{h}}(<3 \mathrm{ng} / \mathrm{mL})$

$\begin{array}{lll}\text { Baseline } & 0 / 78(0) & 0 / 74(0) \\ \text { At } 5 \text { months } & 0 / 84(0) & 0 / 84(0)\end{array}$

Marginal folate deficiency ${ }^{\mathrm{h}}$ ( $\geq 3$ and $<6 \mathrm{ng} / \mathrm{mL}$ )

$\begin{array}{lll}\text { Baseline } & 21 / 78(27) & 24 / 74(32) \\ \text { At } 5 \text { months } & 10 / 84(12) & 18 / 84(21)\end{array}$

Vitamin B12 deficiency $(<148$ pmol/L)

$\begin{array}{lll}\text { Baseline } & 0 / 83(0) & 1 / 84(1) \\ \text { At } 5 \text { months } & \text { NA } & \text { NA }\end{array}$

Marginal vitamin B12 deficiency ${ }^{i}(\geq 148$ and $<222$ pmol/L)
Baseline
2/83 (2)
$5 / 84(6)$
At 5 months
NA
NA

$B M I$ Body mass index, $H b$ Hemoglobin, FER Ferritin, sTfR Soluble transferrin receptor, RBP Retinol-binding protein, NA Not available

${ }^{a}$ Values are $n /$ total $n(\%)$

${ }^{\text {b}}$ Thereof mild underweight (BMI $\geq 17.0$ and $<18.5 \mathrm{~kg} / \mathrm{m}^{2}$ ): at baseline $n=21$ / $n=18$ (intervention/control), at 5 months $n=19 / n=14$; moderate underweight (BMI $\geq 16.0$ and $<17.0 \mathrm{~kg} / \mathrm{m}^{2}$ ): at baseline $n=6 / n=4$, at 5 months $n=5 / n=6$; severe underweight $\left(\mathrm{BMI}<16.0 \mathrm{~kg} / \mathrm{m}^{2}\right)$ : at baseline $n=2 / n=3$, at 5 months $n=1 / n=3$

'Thereof low-normal BMI (BMI $\geq 18.5$ and $\left.<20.0 \mathrm{~kg} / \mathrm{m}^{2}\right)$ : at baseline $n=24 / n=$ 24 , at 5 months $n=21 / n=24$

${ }^{\mathrm{d}}$ At baseline total $n=170$ ( $n=1 / n=1$ refused blood sampling). At 5 months total $n=171$ ( $n=1$ intervention participant refused blood sampling)

'Thereof mild anemia $(\mathrm{Hb} \geq 11.0$ and $<12.0 \mathrm{~g} / \mathrm{dL})$ : at baseline $n=13 / n=16$, at 5 months $n=16 / n=14$; moderate anemia ( $\mathrm{Hb} \geq 8.0$ and $<11.0 \mathrm{~g} / \mathrm{dL}$ ): at baseline $n=6 / n=7$, at 5 months $n=3 / n=8$

${ }^{\mathrm{f}}$ At baseline total $n=168(n=1 / n=1$ refused blood sampling, $n=1 / n=1$ with missing aliquot). At 5 months total $n=171$ ( $n=1$ intervention participant refused blood sampling)

${ }^{g}$ Values adjusted for subclinical inflammation

${ }^{\mathrm{h}}$ At baseline total $n=152(n=1 / n=1$ refused blood sampling, $n=1 / n=1$ with missing aliquot, $n=6 / n=10$ with deviating duplicate measurement). At 5 months total $n=168$ ( $n=1$ intervention participant refused blood sampling, $n=1 / n=2$ with deviating duplicate measurement)

'At baseline total $n=167$ ( $n=1 / n=1$ refused blood sampling, $n=2 / n=1$ with missing aliquot). Values for vitamin B12 not available at 5 months

participants were distinctly older and to a lesser extent affected by underweight than workers in the present study.

Effects from lunch provision on worker's anthropometric indices might have been weakened due to the frequent onset of infectious diseases, as infections are known to have a negative impact on the nutritional status [40]. At baseline, participants often reported symptoms of respiratory tract infections, fever, and diarrhea, and tended to continue work despite being sick [4].

The study collected qualitative data on the dietary intake through $24 \mathrm{~h}$-recalls among all participants at several interviews during the intervention [19]. Results indicate that some participants tended to skip breakfasts, but hardly ever skipped lunch meals. Therefore, providing lunch to workers replaces meals that are otherwise eaten by the women, mostly low-price options from nearby street vendors and/or home prepared food items. Consequently, total dietary surplus (e.g. of calories, one prerequisite to expect effects on anthropometry) through lunch provision might be restricted. Although skipping of breakfasts somewhat increased in intervention subjects, no significant differences in skipping breakfasts between groups were observed [19]. Yet, skipping of meals in workers with access to a staff canteen should be closely monitored. Moreover, a distinct lower consumption of energy-dense sweets/sugared beverages was noted in intervention participants [19]. This effect is regarded as beneficial for the prevention of noncommunicable chronic diseases although it also lowers total energy intake [41].

Overall, lunches matched recommendations on the energy content of lunch provision through canteens [42], as well as recommendations for sources of food energy [43]. Nevertheless, the RDA of $2115 \mathrm{kcal} /$ day [20] might 
Table 4 Mean BMI, weight, TSF, and MUAMC at baseline and at 5 months (follow-up) by group and the intervention effects in female Cambodian garment workers ${ }^{\mathrm{a}}$

\begin{tabular}{|c|c|c|c|c|c|}
\hline & \multicolumn{2}{|l|}{ Group } & \multicolumn{3}{|l|}{ Intervention effect } \\
\hline & Intervention & Control & Mean difference & Cohen's $d$ & $p$ \\
\hline \multicolumn{6}{|l|}{$\mathrm{BMI}, \mathrm{kg} / \mathrm{m}^{2}$} \\
\hline Baseline & $19.8 \pm 2.4^{b}$ & $19.9 \pm 2.4$ & - & - & - \\
\hline At 5 months, unadjusted & $19.9 \pm 2.3$ & $19.9 \pm 2.4$ & - & - & - \\
\hline At 5 months, adjusted & $20.0(19.8,20.2)^{c}$ & $19.9(19.7,20.0)$ & $0.1(-0.1,0.4)$ & 0.17 & 0.27 \\
\hline \multicolumn{6}{|l|}{ Weight, kg } \\
\hline Baseline & $46.0 \pm 6.1$ & $47.4 \pm 6.3$ & - & - & - \\
\hline At 5 months, unadjusted & $46.4 \pm 5.9$ & $47.6 \pm 5.9$ & - & - & - \\
\hline At 5 months, adjusted & $47.0(46.7,47.4)$ & $46.9(46.5,47.3)$ & $0.1(-0.4,0.7)$ & 0.06 & 0.64 \\
\hline \multicolumn{6}{|l|}{ TSF, mm } \\
\hline Baseline & $15.4 \pm 4.5$ & $15.4 \pm 4.8$ & - & - & - \\
\hline At 5 months, unadjusted & $15.6 \pm 4.7$ & $15.2 \pm 4.6$ & - & - & - \\
\hline At 5 months, adjusted & $15.6(15.1,16.0)$ & $15.2(14.7,15.7)$ & $0.4(-0.3,1.1)$ & 0.18 & 0.24 \\
\hline \multicolumn{6}{|l|}{ MUAMC, $\mathrm{cm}$} \\
\hline Baseline & $19.1 \pm 1.4$ & $19.2 \pm 1.6$ & - & - & - \\
\hline At 5 months, unadjusted & $19.1 \pm 1.5$ & $19.3 \pm 1.5$ & - & - & - \\
\hline At 5 months, adjusted & $19.2(19.0,19.3)$ & $19.3(19.1,19.4)$ & $-0.1(-0.3,0.1)$ & -0.14 & 0.35 \\
\hline
\end{tabular}

BMI Body mass index, TSF Triceps skinfold thickness, MUAMC Mid-upper arm muscle circumference

${ }^{\text {a Total }} n=172$ (completed the follow-up, $n=86$ intervention and $n=86$ control). A general linear model with adjustments for baseline values was used to predict marginal means $(95 \% \mathrm{Cls}$ ) for each outcome variable and to estimate intervention effects as corresponding marginal mean differences ( $95 \%$ Cls) including an estimated standardized effect size (Cohen's $d$ )

${ }^{\mathrm{b}}$ Mean $\pm \mathrm{SD}$ (all such values)

${ }^{c}$ Marginal mean, $95 \% \mathrm{Cl}$ in parentheses (all such values)

underestimate energy requirements among workers, notably in those with a BMI $<20 \mathrm{~kg} / \mathrm{m}^{2}$ and those exposed to heavy work load. Consequently, an adjusted higher amount of calories during lunch provision might be needed to achieve a stronger effect on the BMI of laborers with suboptimal nutritional status. On the other hand, any lunch provision program should also consider the presence of normal weight and overweight workers.

The model lunch sets had a low mean iron content [18]. Due to their relatively high price, animal source foods were served in small portion sizes of $\sim 50 \mathrm{~g} /$ day, equaling $0.5-1.7 \mathrm{mg}$ iron per $100 \mathrm{~g}$ edible portion [18, 44-46]. Consequently, most of the dietary iron was provided as less bioavailable nonheme iron in vegetables, fruits, and rice [18]. As vitamin $C$ enhances nonheme iron absorption, sets provided on average a relatively high amount of vitamin C. But, the effect might have been limited in a complete menu containing various components known to inhibit iron intake [47, 48]. Although data on the dietary iron intake among Cambodian garment workers are missing, the lunch sets could have contained less iron than lunches eaten by the workers outside the factory gates. Alternative and affordable heme iron-rich food items (e.g. blood curd, liver, or certain small fish species) could constitute a suitable option to increase the iron content $[18,49-51]$.
If the obtained overall finding in terms of $\mathrm{Hb}$ represents an intervention effect can be questioned. The unadjusted mean $\mathrm{Hb}$ remained unchanged in intervention participants. However, three out of four study subjects were not anemic at baseline. Therefore, distinct positive effects on mean $\mathrm{Hb}$ concentration could not be expected from the intervention among non-anemic participants. On the other hand, the observed changes in mean $\mathrm{Hb}$ among subjects affected by moderate anemia are considered relevant. The prevalence of anemia was initially expected to be higher, since data indicate that $45 \%$ of Cambodian women of reproductive age are anemic [10]. The recent ILO survey reported a similar high prevalence in female garment workers [9]. Yet, these findings are based on capillary blood analysis. In a recent study among children from Laos, $\mathrm{Hb}$ concentration by HemoCue was significantly higher in venous blood samples compared to capillary blood, resulting in different anemia prevalence data [52]. Although $\mathrm{Hb}$ measurement via HemoCue is thought to be more reliable in venous samples [53], some report that HemoCue showed poor agreement compared with automated hematology analyzers [52].

Iron deficiency is believed to be the primary cause of anemia [11]. However, as previously mentioned, the iron content of the studied lunch sets was relatively low [18]. On the other hand, iron deficiency can only partially 
Table 5 Mean Hb, FER, sTfR, RBP and folate concentrations at baseline and at 5 months (follow-up) by group and the intervention effects in female Cambodian garment workers ${ }^{a}$

\begin{tabular}{|c|c|c|c|c|c|}
\hline & \multicolumn{2}{|l|}{ Group } & \multicolumn{3}{|l|}{ Intervention effect } \\
\hline & Intervention & Control & Mean difference & Cohen's d & $p$ \\
\hline \multicolumn{6}{|l|}{$\mathrm{Hb}, \mathrm{g} / \mathrm{dL}$} \\
\hline Baseline & $12.6 \pm 0.9(85)^{\mathrm{b}}$ & $12.4 \pm 1.0(85)$ & - & - & - \\
\hline At 5 months, unadjusted & $12.6 \pm 0.9(85)$ & $12.3 \pm 1.0(86)$ & - & - & - \\
\hline At 5 months, adjusted ${ }^{c}$ & $12.5(12.4,12.6)(85)^{d}$ & $12.4(12.3,12.5)(85)$ & $0.1(-0.1,0.3)$ & 0.17 & 0.30 \\
\hline \multicolumn{6}{|l|}{$\mathrm{FER}, \mu \mathrm{g} / \mathrm{L}^{\mathrm{e}}$} \\
\hline Baseline & $40.4 \pm 33.8(84)$ & $44.9 \pm 40.0(84)$ & - & - & - \\
\hline At 5 months, unadjusted & $38.0 \pm 27.1(85)$ & $47.4 \pm 39.6(86)$ & - & - & - \\
\hline At 5 months, adjusted ${ }^{c}$ & $39.3(35.5,43.0)(84)$ & $45.8(42.1,49.6)(84)$ & $-6.6(-11.9,-1.3)$ & -0.39 & 0.015 \\
\hline \multicolumn{6}{|l|}{ sTfR, mg/L } \\
\hline Baseline & $5.8 \pm 2.6(84)$ & $6.3 \pm 3.3(84)$ & - & - & - \\
\hline At 5 months, unadjusted & $5.9 \pm 2.6(85)$ & $6.2 \pm 3.5(86)$ & - & - & - \\
\hline At 5 months, adjusted ${ }^{c}$ & $6.1(5.9,6.3)(84)$ & $5.9(5.7,6.1)(84)$ & $0.2(-0.1,0.5)$ & 0.23 & 0.15 \\
\hline \multicolumn{6}{|l|}{$\mathrm{RBP}, \mu \mathrm{mol} / \mathrm{L}^{\mathrm{e}}$} \\
\hline Baseline & $1.37 \pm 0.26(84)$ & $1.49 \pm 0.31$ & - & - & - \\
\hline At 5 months, unadjusted & $1.42 \pm 0.33(85)$ & $1.44 \pm 0.35(86)$ & - & - & - \\
\hline At 5 months, adjusted ${ }^{c}$ & $1.45(1.39,1.52)(84)$ & $1.40(1.34,1.47)(84)$ & $0.05(-0.04,0.14)$ & 0.17 & 0.27 \\
\hline \multicolumn{6}{|l|}{ Folate, ng/mL } \\
\hline Baseline & $8.0 \pm 3.1(78)$ & $7.8 \pm 2.9(74)$ & - & - & - \\
\hline At 5 months, unadjusted & $9.6 \pm 4.5(84)$ & $8.2 \pm 3.2(84)$ & - & - & - \\
\hline At 5 months, adjusted ${ }^{c}$ & $9.5(8.8,10.3)(78)$ & $8.4(7.6,9.2)(73)$ & $1.1(-0.02,2.2)$ & 0.32 & 0.054 \\
\hline
\end{tabular}

$\mathrm{Hb}$ Hemoglobin, FER Ferritin, sTfR Soluble transferrin receptor, RBP Retinol binding protein

${ }^{a} \mathrm{~A}$ general linear model with adjustments for baseline values was used to predict marginal means (95\% Cls) for each outcome variable and to estimate intervention effects as corresponding marginal mean differences ( $95 \% \mathrm{Cls}$ ) including an estimated standardized effect size (Cohen's $d$ )

${ }^{\mathrm{b}}$ Mean $\pm \mathrm{SD}, n$ in parentheses (all such values)

${ }^{c}$ Among subjects with data for both time points

${ }^{\mathrm{d}}$ Marginal mean, $95 \% \mathrm{Cl}$ and $n$ in parentheses (all such values)

eValues adjusted for subclinical inflammation

explain anemia in this study population [4], as the prevalence of iron deficiency anemia among subjects was solely $12 \%$. Strategies to improve zinc and folate status, as well as to treat and prevent hookworm infections, have been suggested [54]. In addition, genetic disorders, e.g. $\mathrm{Hb} \mathrm{E}$ variants and $\alpha$-thalassemia, are reported to affect $>50 \%$ of the Cambodian population, causing lower $\mathrm{Hb}$ concentrations regardless of iron stores [16, 54-57]. In a recent one-year randomized controlled trial, neither iron ingots added to cooking pots nor daily iron supplements $(18 \mathrm{mg} /$ d) increased $\mathrm{Hb}$ concentration in anemic Cambodian women [58]. In comparison, daily high-dose iron supplementation $(60 \mathrm{mg} / \mathrm{d})$ for 12 weeks increased $\mathrm{Hb}$ in a female study population in Cambodia, while added multiple micronutrients did not confer additional benefits [56].

None of the study subjects were affected by frank VitA deficiency and only few participants showed a marginal VitA status at baseline, which is in line with recent national representative data for women of reproductive age $[34,54]$. The uptake of VitA from the diet is under homeostatic control [59], consequently, no effects on RBP concentrations could be expected in VitA-replete subjects. The overall trend on increasing RBP, is largely based on the increase of mean RBP in few intervention subjects with marginal VitA deficiency, which is expected to be relevant, but confirmation is needed in a larger study including more participants with suboptimal VitA status. At the time of planning, the study population was expected to be more affected by a poor VitA status, given foregoing findings [60].

The results suggest that lunch sets provided a beneficial amount of dietary folate. The estimated mean folate content among sets was corresponding to $44 \%$ of the SEA-RDA [20]. In addition, missing folate data in local food composition tables certainly led to an underestimation for some lunch sets [18]. The finding on the prevalence of marginal folate deficiency among workers is in line with previous reports that suggest measures to increase folate/folic acid intake of Cambodian women [54]. According to the subgroup analysis, the trend on 

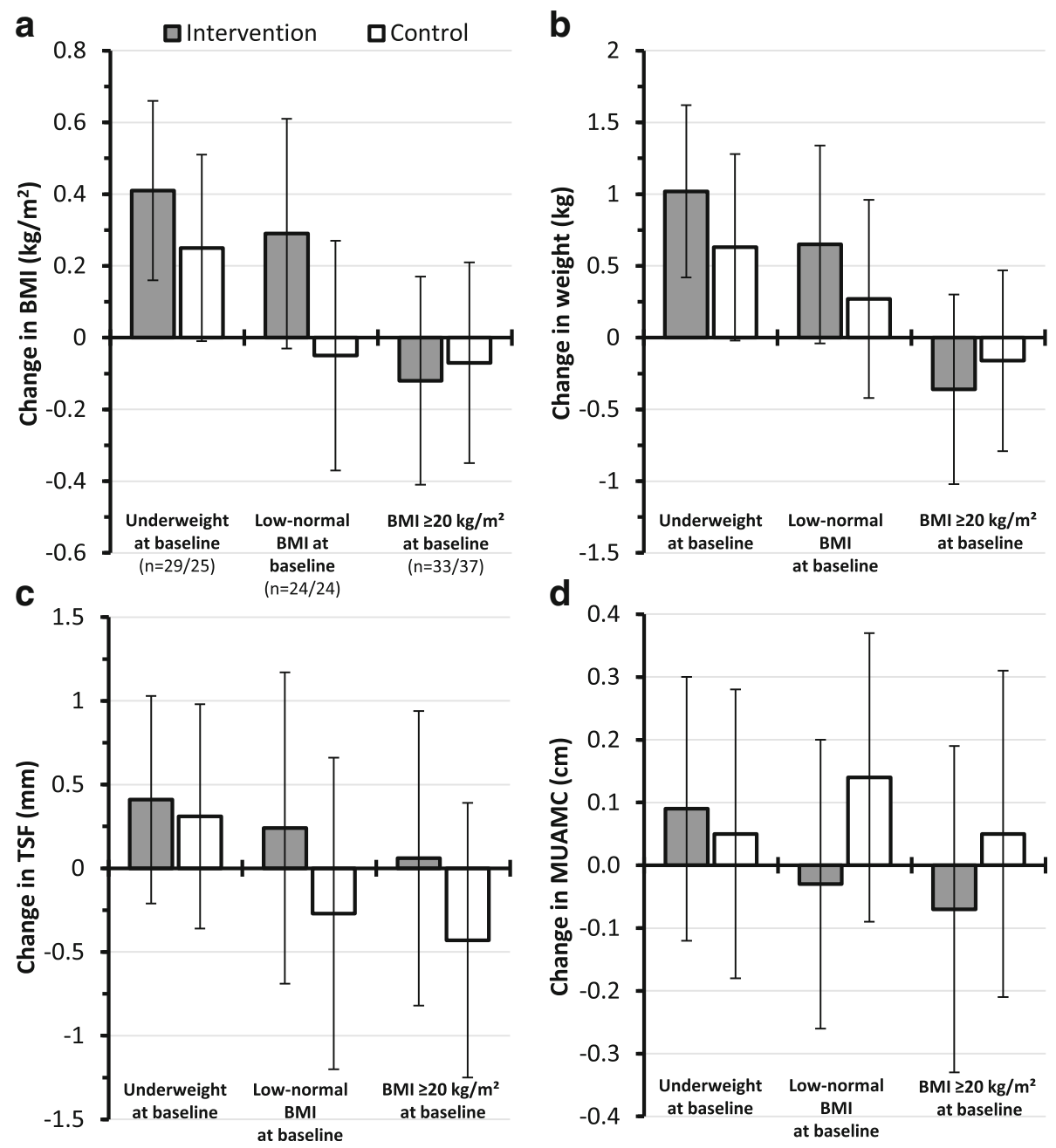

Fig. 2 Mean change in a BMI, b weight, c TSF, and $\mathbf{d}$ MUAMC from baseline to 5 months (follow-up) by group and BMl status at baseline. Total $n=172$ (completed the follow-up, $n=86$ intervention and $n=86$ control). Thereof underweight (BMl $<18.5 \mathrm{~kg} / \mathrm{m}^{2}$ ) at baseline: $n=29 / n=25$ (intervention/control); low-normal BMI (BMI $\geq 18.5$ and $<20 \mathrm{~kg} / \mathrm{m}^{2}$ ) at baseline: $n=24 / n=24$; and BMI $\geq 20 \mathrm{~kg} / \mathrm{m}^{2}$ at baseline: $n=33 / n=37$. A general linear model with adjustments for baseline values was used to predict marginal mean changes (95\% Cls) for each outcome variable. Whiskers illustrate corresponding 95\% Cls. BMI: Body mass index; TSF: Triceps skinfold thickness; MUAMC: Mid-upper arm muscle circumference.

folate status not only concerned participants with marginal folate deficiency, but also subjects with adequate folate status. However, a part of the increase in folate concentration among intervention participants with marginal folate status can be attributed to the upregulation of folate uptake from the diet [61], as represented by the increase in mean folate in control participants with a marginal folate status.

\section{Limitations of the study}

Results of this study are related to the setting and the specific study population. However, the status of the laborers and the working conditions were assumed to be comparable with general conditions in the Cambodian garment industry. Moreover, the study's inclusion criteria represented a greater part of workers employed by this sector.

The model lunch sets could not be based on the study's baseline findings [4] nor on any other previous gap-oriented assessment. An appropriate intervention duration, as well as proper amounts of calories or micronutrients, to specifically target underweight, anemia and/or micronutrient deficiencies, could not be established beforehand. Furthermore, the estimation of the lunches' nutritive value was limited [18]. For instance, no information was available about components known to inhibit iron bioavailability.

Fear and skepticism related to the blood sampling were reported by workers, notably due to a severe HIV outbreak caused by clinicians reusing syringes shortly before enrollment [62]. Moreover, the factory 


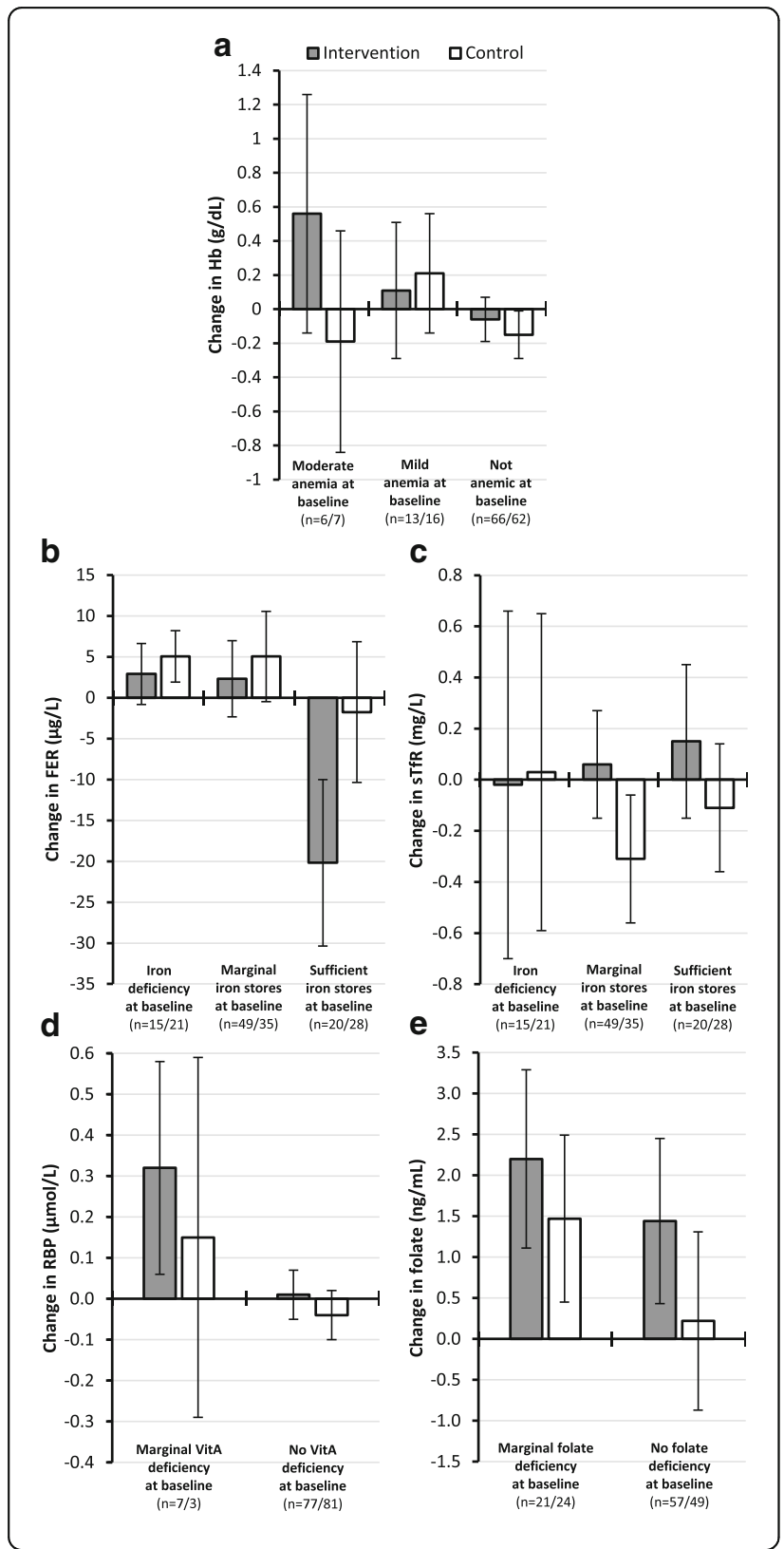

unexpectedly changed its main purchaser and a part of its management at the time when the study started. As a consequence, a part of the total factory staff, and therefore also a relatively high number of workers who had already signed consents or were already enrolled, ceased the work and left the factory between April and June 2015. Almost all study dropouts fell in this period. Yet, they were equally distributed across groups and their sociodemographic characteristics were comparable to those who completed the study (data not shown). Given the high fluctuation rate, the impact assessment was performed after 5 months already. As the number of data sets was smaller than targeted, this clearly limited the statistical power and the effect sizes that could be
Fig. 3 Mean change in a Hb, b FER, c sTfR, d RBP, and e folate concentrations from baseline to 5 months (follow-up) by group and status at baseline. A general linear model with adjustments for baseline values was used to predict marginal mean changes (95\% Cls) for each outcome variable. Whiskers illustrate corresponding 95\% Cls. a Mean change of $\mathrm{Hb}$ for subjects with moderate anemia $(\mathrm{Hb} \geq 8.0$ and $<11.0 \mathrm{~g} / \mathrm{dL}$ ), mild anemia $(\mathrm{Hb} \geq 11.0$ and $<12.0 \mathrm{~g} / \mathrm{dL})$, and no anemia ( $\mathrm{Hb} \geq 12.0 \mathrm{~g} / \mathrm{dL}$ ) at baseline. Total $n=85 / n=85$ (intervention/control). b Mean change of FER for subjects with iron deficiency (FER $<15 \mu \mathrm{g} / \mathrm{L}$ ), marginal iron stores (FER $\geq 15$ and $<$ $50 \mu \mathrm{g} / \mathrm{L}$ ), and sufficient iron stores (FER $\geq 50 \mu \mathrm{g} / \mathrm{L}$ ) at baseline. Total $n=84 / n=84$. Values adjusted for subclinical inflammation. c Mean change of sTfR for subjects with iron deficiency, marginal iron stores, and sufficient iron stores at baseline. Total $n=84 / n=84$. d Mean change of RBP for subjects with marginal VitA deficiency (RBP $\geq 0.70$ and $<1.05 \mu \mathrm{mol} / \mathrm{L}$ ) and no VitA deficiency (RBP $\geq 1.05 \mu \mathrm{mol} / \mathrm{L}$ ) at baseline. Total $n=84 / n=84$. Values adjusted for subclinical inflammation. e Mean change of folate for subjects with marginal folate deficiency (folate $\geq 3$ and $<6 \mathrm{ng} / \mathrm{mL}$ ) and no folate deficiency (folate $\geq 6 \mathrm{ng} / \mathrm{mL}$ ) at baseline. Total $n=78 / n=73$. Hb: Hemoglobin; FER: Ferritin; sTfR: Soluble transferrin receptor; RBP: Retinol binding protein; VitA: Vitamin A.

measured. In line with guidelines for exploratory studies, no corrections for multiple comparisons have been made [63].

Only a part of the enrolled workers where actually affected by underweight, anemia and/or micronutrient deficiencies. However, direct improvements can only be expected in malnourished individuals. The subgroup analysis was based on relatively small sample sizes, holding a descriptive character, and indicating trends only. The calculation of the sample size of future studies may consider the initial prevalence of malnutrition.

The prevalence of hemoglobinopathies, which are likely to be a contributing factor to anemia, was not measured. Inherited hemoglobin disorders are also known to impact on markers of iron status [16, 64]. Furthermore, menstrual blood loss, a determinant of iron stores in women of reproductive age [65], could not be recorded.

\section{Conclusions}

After 5 months of lunch provision, anthropometric variables merely showed non-significant marginal distinctions between the intervention and the control group. Yet, subgroup analysis prompts that effects differ according to the initial status of workers. For instance, the positive impact on BMI and weight was found more pronounced in women with a poor or marginal nutritional status. However, given the low sample size in subgroups, trends, but no definite inferences can be stated. Overall, only minor non-significant positive differences were noticed in $\mathrm{Hb}$ and VitA status for the intervention participants. Specific results indicate that the model lunch sets need to be revisited for iron content and/or iron bioavailability, as interventions subjects showed significantly lower FER values at the follow-up. On the other hand, 
endline folate status was higher in workers with access to the lunch provision, although insignificantly, advising that lunch sets provided a relevant amount of dietary folate. In conclusion, lunch provision through a canteen for Cambodian garment workers is feasible and is believed to have the potential to result in positive effects on anthropometry, $\mathrm{Hb}$, and micronutrient status, particularly in malnourished individuals. The authors suggest that similar trials with larger study populations, which include lunch sets adapted to identified requirements of workers affected by underweight, anemia and/ or definite micronutrient deficiencies, should be performed. The overall findings from this study should have practical implications for the design and implementation of subsequent studies, lunch programs, and further strategies aiming at the improvement of the nutritional situation of female garment workers in Cambodia.

\begin{abstract}
Abbreviations
AGP: a1-acid-glycoprotein; Al: Adequate intake; BMI: Body mass index; CDC: Centers for Disease Control and Prevention; Cl: Confidence interval; CRP: C-reactive protein; FER: Ferritin; Hb: Hemoglobin; HIV: Human immunodeficiency virus; ILO: International Labour Organization; Kcal: Kilocalories; LUPROGAR: Lunch provision in garment factories; Max.: Maximum; Min.: Minimum; MUAC: Mid upper-arm circumference; MUAMC: Mid upper-arm muscle circumference; NGO: Non-government organization; RAE: Retinol activity equivalent; RBP: Retinol binding protein; RDA: Recommended dietary allowance; SD: Standard deviation;

SEA: Southeast Asia; sTfR: Soluble transferrin receptor; TSF: Triceps skinfold thickness; USD: United States Dollar; VitA: Vitamin A; VitB12: Vitamin B12
\end{abstract}

\section{Acknowledgements}

We thank Khov Chhay (Managing Director) and the management of Apsara Garment Co. Ltd., Phnom Penh, Cambodia, for their unrestricted help to implement the study; Rapytha Bonamy (Managing Director) and the staff of Hagar Catering and Facilities Management Ltd., Phnom Penh, Cambodia, for the collaboration in establishing and operating the staff canteen; Juergen Erhardt, VitMin Laboratory, Willstaett, Germany, and the Pasteur Institute, Phnom Penh, Cambodia, for conducting the serum biomarker analyses; staff at the Department of Fisheries Post-Harvest Technologies and Quality Control, Fisheries Administration, Ministry of Agriculture, Forestry and Fisheries, Phnom Penh, Cambodia, and Hanna Friedrich, MSc student at Justus Liebig University, Giessen, Germany, for their support in implementation and data collection.

\section{Authors' contributions}

JM and MBK conceived and designed the LUPROGAR trial; JM and NB conducted the field work and managed the data; FTW and CC supported and supervised data collection in the field; JM conducted the statistical analysis of the data; JM wrote the initial manuscript; all authors contributed to the review and editing of the manuscript to the final version; and JM and MBK had primary responsibility for the final content. All authors read and approved the final version of the manuscript.

\section{Funding}

The LUPROGAR study was conducted with financial support from the German Federal Ministry of Economic Cooperation and Development (BMZ). NB received a travel grant from the Fiat Panis Foundation, Ulm, Germany. Costs to publish in open access were partially covered by the open access publication fund of the Justus Liebig University, Giessen, Germany. The funding sponsors had no role in the design of the study; in the collection, analyses, or interpretation of data; in the writing of the manuscript, and in the decision to publish the results.

\section{Availability of data and materials}

The datasets generated and analyzed during the study are not publicly available due the terms of consent to which the participants agreed but are available from the corresponding author on reasonable request.

\section{Ethics approval and consent to participate}

This trial was conducted according to the guidelines laid down in the Declaration of Helsinki. Ethical approval on all procedures was obtained from the Institutional Review Board of the Faculty of Medicine at Justus Liebig University, Giessen, Germany (14 November 2014, Identifier: 198/14) and the National Ethics Committee for Health Research at the Ministry of Health, Phnom Penh, Cambodia (29 December 2014, Identifier: 0363 NECHR). Written informed consent was collected from all subjects. Participants were informed that they could leave the study at any time.

\section{Consent for publication}

Not applicable.

\section{Competing interests}

The authors declare that they have no competing interests.

\section{Author details}

${ }^{1}$ Institute of Nutritional Sciences, Justus Liebig University Giessen, Wilhelmstrasse 20, 35392 Giessen, Germany. ${ }^{2}$ UMR 204 Nutripass, Institut de Recherche pour le Développement (IRD), IRD / UM / SupAgro, 911 Avenue d' Agropolis, 34394 Montpellier, France. ${ }^{3}$ Department of Fisheries Post-Harvest Technologies and Quality Control (DFPTQ), Fisheries Administration, Ministry of Agriculture, Forestry, and Fisheries, 186 Preah Norodom Boulevard, 12000 Phnom Penh, Cambodia.

Received: 3 September 2018 Accepted: 12 June 2019

Published online: 08 July 2019

\section{References}

1. International Labour Organization. Cambodian garment and footwear sector bulletin. Issue 6 . What explains strong export and weak employment figures in the Cambodian garment sector? Phnom Penh: International Labour Organization; 2017.

2. International Labour Organization. Cambodian garment and footwear sector bulletin. Issue 5 . Recent trade policy developments and possible implications for Cambodia's garment and footwear sector. Phnom Penh: International Labour Organization; 2017.

3. McMullen A. Shop'til they drop. Fainting and malnutrition in garment workers in Cambodia. Phnom Penh: Labour Behind the Label \& Community Legal Education Centre; 2013.

4. Makurat J, Friedrich $\mathrm{H}$, Kuong K, Wieringa FT, Chamnan C, Krawinkel MB. Nutritional and micronutrient status of female workers in a garment factory in Cambodia. Nutrients. 2016:8:694.

5. Bargawi O. Cambodia's garment industry - origins and future prospects. London: Overseas Development Institute; 2005.

6. Asuyama Y, Neou S. Chapter 3. How has the Cambodian garment industry evolved? In: Fukunishi T, editor. Dynamics of the garment industry in low-income countries: experience of Asia and Africa. Chiba: Japan External Trade Organization; 2012.

7. Kang C, Liv D. Living wage survey for Cambodia's garment industry. Phnom Penh: Cambodia Institute of Development Study; 2009.

8. International Labour Organization. World Bank. Cambodia. Women and work in the garment industry. Phnom Penh: International Labour Organization; 2006.

9. International Labour Organization. Garment workers' health and nutrition status, and food provision in factories. A study from selected enterprises in Cambodia. Phnom Penh: International Labour Organization; 2016.

10. National Institute of Statistics; Directorate General for Health; ICF International. Cambodia demographic and health survey 2014. Maryland: National Institute of Statistics; Directorate General for Health; ICF international: Phnom Penh, Cambodia and Rockville; 2015.

11. World Health Organization. Iron deficiency anaemia. assessment, prevention, and control: a guide for programme managers. Geneva: World Health Organization; 2001. 
12. World Health Organization. Physical status: the use and interpretation of anthropometry: report of a WHO expert committee. Geneva: World Health Organization; 1995.

13. Black RE, Victora CG, Walker SP, Bhutta ZA, Christian P, de Onis M, Ezzati M, Grantham-McGregor S, Katz J, Martorell R, et al. Maternal and child undernutrition and overweight in low-income and middle-income countries. Lancet. 2013;382:427-51.

14. Koury MJ, Ponka P. New insights into erythropoiesis: the roles of folate, vitamin B12, and iron. Annu Rev Nutr. 2004;24:105-31.

15. Charles CV, Summerlee AJ, Dewey CE. Anemia in Cambodia: prevalence, etiology and research needs. Asia Pac J Clin Nutr. 2012;21:171-81.

16. Karakochuk CD, Whitfield KC, Barr SI, Lamers Y, Devlin AM, Vercauteren SM, Kroeun H, Talukder A, McLean J, Green TJ. Genetic hemoglobin disorders rather than iron deficiency are a major predictor of hemoglobin concentration in women of reproductive age in rural Prey Veng, Cambodia. J Nutr. 2015;145:134-42.

17. BDLINK; HRINC. Study on the perceptions of garment factory owners on nutrition and the feasibility for pursuing canteen services in the garment sector in Cambodia. Phnom Penh: International Labour Organization; 2012.

18. Makurat J, Pillai A, Wieringa FT, Chamnan C, Krawinkel MB. Estimated nutritive value of low-price model lunch sets provided to garment workers in Cambodia. Nutrients. 2017;9:782.

19. Makurat J, Kretz EC, Wieringa FT, Chamnan C, Krawinkel MB. Dietary diversity in Cambodian garment workers: the role of free lunch provision. Nutrients. 2018;10:1010.

20. Barba CV, Cabrera MI. Recommended dietary allowances harmonization in Southeast Asia. Asia Pac J Clin Nutr. 2008;17(Suppl 2):405-8.

21. Nishida C, Martinez Nocito F. FAO/WHO scientific update on carbohydrates in human nutrition: introduction. Eur J Clin Nutr. 2007;61(Suppl 1):S1-4.

22. Khan NC, van Hoan P. Vietnam recommended dietary allowances 2007. Asia Pac J Clin Nutr. 2008;17(Suppl 2):409-15.

23. Food and Nutrition Board; Institute of Medicine of the National Academies. Dietan reference intakes for energy, carbohydrate, fiber, fat, fatty acids, cholesterol, protein and amino acids. Washington DC: The National Academies Press; 2005.

24. Centers for Disease Control and Prevention. National health and nutrition examination survey (NHANES). Anthropometry procedures manual. Atlanta: Centers for Disease Control and Prevention; 2007.

25. Morisaki N, Nagata C, Jwa SC, Sago H, Saito S, Oken E, Fujiwara T. Prepregnancy BMI-specific optimal gestational weight gain for women in Japan. J Epidemiol. 2017;27:492-8.

26. Gibson RS. Principles of nutritional assessment. New York: Oxford University Press; 2005

27. Erhardt JG, Estes JE, Pfeiffer CM, Biesalski HK, Craft NE. Combined measurement of ferritin, soluble transferrin receptor, retinol binding protein and C-reactive protein by an inexpensive, sensitive, and simple sandwich enzyme-linked immunosorbent assay technique. J Nutr. 2004;134:3127-32.

28. Pfeiffer CM, Zhang M, Lacher DA, Molloy AM, Tamura T, Yetley EA, Picciano MF, Johnson CL. Comparison of serum and red blood cell folate microbiologic assays for national population surveys. J Nutr. 2011:141:1402-9.

29. Thurnham DI, McCabe LD, Haldar S, Wieringa FT, Northrop-Clewes CA, McCabe GP. Adjusting plasma ferritin concentrations to remove the effects of subclinical inflammation in the assessment of iron deficiency: a metaanalysis. Am J Clin Nutr. 2010;92:546-55

30. Milman N. Iron in pregnancy: how do we secure an appropriate iron status in the mother and child? Ann Nutr Metab. 2011:59:50-4.

31. Thurnham DI, Northrop-Clewes CA, Knowles J. The use of adjustment factors to address the impact of inflammation on vitamin a and iron status in humans. J Nutr. 2015;145:1137S-43S.

32. Gamble MV, Ramakrishnan R, Palafox NA, Briand K, Berglund L, Blaner WS. Retinol binding protein as a surrogate measure for serum retinol: studies in vitamin A-deficient children from the Republic of the Marshall Islands. Am J Clin Nutr. 2001;73:594-601.

33. Thurnham DI, McCabe GP, Northrop-Clewes CA, Nestel P. Effects of subclinical infection on plasma retinol concentrations and assessment of prevalence of vitamin A deficiency: meta-analysis. Lancet. 2003;362:2052-8.

34. Wieringa FT, Sophonneary P, Whitney S, Mao B, Berger J, Conkle J, Dijkhuizen MA, Laillou A. Low prevalence of iron and vitamin A deficiency among Cambodian women of reproductive age. Nutrients. 2016;8:197.

35. World Health Organization. Serum and red blood cell folate concentrations for assessing folate status in populations. Geneva: World Health Organization; 2012
36. Allen LH. How common is vitamin B-12 deficiency? Am J Clin Nutr. 2009:89:693S-6S

37. Cohen J. A power primer. Psychol Bull. 1992;112:155-9.

38. Filmer D, Pritchett LH. Estimating wealth effects without expenditure dataor tears: an application to educational enrollments in states of India. Demography. 2001;38:115-32.

39. Jomaa LH, McDonnell E, Probart C. School feeding programs in developing countries: impacts on children's health and educational outcomes. Nutr Rev. 2011;69:83-98.

40. Krawinkel MB. Interaction of nutrition and infections globally: an overview. Ann Nutr Metab. 2012;61(Suppl 1):39-45.

41. World Health Organization. Guideline: sugars intake for adults and children. Geneva: World Health Organization; 2015.

42. German Nutrition Society (DGE). DGE-Qualitätsstandard für die Betriebsverpflegung. Bonn: German Nutrition Society (DGE); 2015.

43. FAO/WHO/UNU. Human energy requirements: report of a joint $\mathrm{FAO} / \mathrm{WHO} /$ UNU expert consultation, Rome, 17-24 October 2001. Rome: FAO; 2004

44. SMILING Consortium Group. Food composition table for Cambodia. Rome: Food and Agricultural Organization; 2013.

45. Institute of Nutrition, Mahidol University, Thailand. ASEAN food composition database. Bangkok: Institute of Nutrition, Mahidol University; 2014.

46. National Institute of Nutrition Vietnam. Nutritive composition table of Vietnamese foods. Hanoi: National Institute of Nutrition Vietnam; 2000.

47. Collings R, Harvey LJ, Hooper L, Hurst R, Brown TJ, Ansett J, King M, Fairweather-Tait SJ. The absorption of iron from whole diets: a systematic review. Am J Clin Nutr. 2013;98:65-81.

48. Cook JD, Reddy MB. Effect of ascorbic acid intake on nonheme-iron absorption from a complete diet. Am J Clin Nutr. 2001;73:93-8.

49. Roos N, Thorseng H, Chamnan C, Larsen T, Gondolf UH, Bukhave K, Thilsted $\mathrm{SH}$. Iron content in common Cambodian fish species: perspectives for dietary iron intake in poor, rural households. Food Chem. 2007;104:1226-35.

50. Roos N, Wahab MA, Chamnan C, Thilsted SH. The role of fish in food-based strategies to combat vitamin A and mineral deficiencies in developing countries. J Nutr. 2007:137:1106-9.

51. Kongkachuichai $R$, Napatthalung $P$, Charoensiri R. Heme and nonheme iron content of animal products commonly consumed in Thailand. J Food Compos Anal. 2002;15:389-98.

52. Hinnouho GM, Barffour MA, Wessells KR, Brown KH, Kounnavong S Chanhthavong B, Ratsavong K, Kewcharoenwong C, Hess SY. Comparison of haemoglobin assessments by HemoCue and two automated haematology analysers in young Laotian children. J Clin Pathol. 2018;71:532-8.

53. Sanchis-Gomar F, Cortell-Ballester J, Pareja-Galeano H, Banfi G, Lippi G. Hemoglobin point-of-care testing: the HemoCue system. J Lab Autom. 2013;18:198-205.

54. Wieringa F, Dahl M, Chamnan C, Poirot E, Kuong K, Sophonneary P, Sinuon M, Greuffeille V, Hong R, Berger J, et al. The high prevalence of anemia in Cambodian children and women cannot be satisfactorily explained by nutritional deficiencies or hemoglobin disorders. Nutrients. 2016;8:348.

55. Carnley BP, Prior JF, Gilbert A, Lim E, Devenish R, Sing H, Sarin E, Guhadasan $R$, Sullivan SG, Wise CA, et al. The prevalence and molecular basis of hemoglobinopathies in Cambodia. Hemoglobin. 2006;30:463-70.

56. Karakochuk CD, Barker MK, Whitfield KC, Barr SI, Vercauteren SM, Devlin AM, Hutcheon JA, Houghton LA, Prak S, Hou K, et al. The effect of oral iron with or without multiple micronutrients on hemoglobin concentration and hemoglobin response among nonpregnant Cambodian women of reproductive age: a $2 \times 2$ factorial, double-blind, randomized controlled supplementation trial. Am J Clin Nutr. 2017;106:233-44.

57. Weatherall DJ, Clegg JB. Inherited haemoglobin disorders: an increasing global health problem. Bull World Health Organ. 2001;79:704-12.

58. Rappaport Al, Whitfield KC, Chapman GE, Yada RY, Kheang KM, Louise J, Summerlee AJ, Armstrong GR, Green TJ. Randomized controlled trial assessing the efficacy of a reusable fish-shaped iron ingot to increase hemoglobin concentration in anemic, rural Cambodian women. Am J Clin Nutr. 2017;106:667-74.

59. Tanumihardjo SA, Russell RM, Stephensen CB, Gannon BM, Craft NE, Haskell MJ, Lietz G, Schulze K, Raiten DJ. Biomarkers of nutrition for development (BOND)-vitamin A review. J Nutr. 2016;146:1816S-48S.

60. Anderson VP, Jack S, Monchy D, Hem N, Hok P, Bailey KB, Gibson RS. Coexisting micronutrient deficiencies among stunted Cambodian infants and toddlers. Asia Pac J Clin Nutr. 2008;17:72-9.

61. Said HM, Chatterjee N, Haq RU, Subramanian VS, Ortiz A, Matherly LH, Sirotnak FM, Halsted C, Rubin SA. Adaptive regulation of intestinal 
folate uptake: effect of dietary folate deficiency. Am J Phys Cell Phys. 2000;279:C1889-95.

62. Seangly P, Cuddy A. Doctor gets 25 years for HIV outbreak. The Phnom Penh Post; 2015.

63. Bender R, Lange S. Adjusting for multiple testing--when and how? J Clin Epidemiol. 2001;54:343-9.

64. Karakochuk CD, Whitfield KC, Rappaport Al, Barr SI, Vercauteren SM, McLean J, Prak S, Hou K, Talukder A, Devenish R, et al. The homozygous hemoglobin EE genotype and chronic inflammation are associated with high serum ferritin and soluble transferrin receptor concentrations among women in rural Cambodia. J Nutr. 2015;145:2765-73.

65. Harvey $L$, Armah CN, Dainty JR, Foxall RJ, John Lewis D, Langford $N J$, Fairweather-Tait SJ. Impact of menstrual blood loss and diet on iron deficiency among women in the UK. Br J Nutr. 2005;94:557-64.

\section{Publisher's Note}

Springer Nature remains neutral with regard to jurisdictional claims in published maps and institutional affiliations.

Ready to submit your research? Choose BMC and benefit from:

- fast, convenient online submission

- thorough peer review by experienced researchers in your field

- rapid publication on acceptance

- support for research data, including large and complex data types

- gold Open Access which fosters wider collaboration and increased citations

- maximum visibility for your research: over $100 \mathrm{M}$ website views per year

At BMC, research is always in progress.

Learn more biomedcentral.com/submissions 